\title{
AGROTEKNIKA
}

ISSN: 2685-3450 (Online)

www.agroteknika.id

ISSN: 2685-3450 (Print)

\section{Pengaruh Pemakaian Jenis Biochar pada Sifat Kimia Tanah P dan K terhadap Perkembangan Vegetatif Tanaman Kelapa Sawit (Elaeis guineensis Jacq.) pada Media Tanam Ultisol}

\section{The Effect of the Use of Biochar Types on the Chemical Properties of $P$ and $K$ Soil on the Vegetative Development of Oil Palm Plants (Elaeis guineensis Jacq.) on Ultisol Planting Media}

\author{
Ingrid Ovie Yosephine*, Hari Gunawan, Rahmad Kurniawan
}

Program Studi Budidaya Perkebunan, Sekolah Tinggi Ilmu Pertanian Agribisnis Perkebunan, Medan, Indonesia

\author{
*Penulis Korespondensi \\ Email: ingrid_ovie@stipap.ac.id
}

\begin{abstract}
Abstrak. Pengaplikasian tempurung kelapa sawit, sekam padi, tongkol jagung serta batok kelapa memberikan hasil reaksi perkembangan yang nampak pada perkembangan vegetatif tanaman kelapa sawit (Elaeis guineensis Jacq.) sesi pembibitan utama. Tujuan riset ini merupakan mengenali pengaruh aplikasi biochar tempurung kelapa sawit, sekam padi, tongkol jagung, serta batok kelapa dan memperoleh dosis biochar yang sesuai pada perkembangan tanaman kelapa sawit (Elaeis guineensis Jacq.) di pembibitan utama. Rancangan yang digunakan dalam riset tersebut merupakan Rancangan Acak Kelompok (RAK) non faktorial dengan 3 pengulangan. Ada pula aspek perlakuan yang digunakan merupakan BO (pupuk majemuk), B1 Biochar sekam padi (50 gr/polybag), B2 Biochar tempurung kelapa sawit (50 gr/polybag), B3 Biochar tongkol jagung (50 gr/polybag), B4 Biochar batok kelapa (50 gr/polybag). Parameter yang diamati merupakan tinggi tanaman (cm), diameter batang (cm), jumlah daun (helai), berat basah akar (gr), berat kering akar (gr), serta analisis $\mathrm{pH}$, hara $P$, serta hara K pada tanah. Hasil menampilkan kalau perlakuan biochar cangkang kelapa sawit, sekam padi, tongkol jagung serta batok kelapa tidak mempengaruhi nyata terhadap parameter yang diamati semacam tinggi tanaman (cm), diameter batang $(\mathrm{cm})$, jumlah daun (helai), berat basah pangkal (gr) dan berat kering pangkal (gr). Sebaliknya pada analisis tanah, perlakuam biochar bisa menaikkan $\mathrm{pH}$, hara $P$, serta hara K tetapi hanya sedikit.
\end{abstract}

Kata kunci: biochar, ultisol, kelapa sawit, vegetatif

Abstract. The application of oil palm shells, rice husks, corn cobs, and coconut shells gave the results of a developmental reaction that was seen in the vegetative development of oil palm plants (Elaeis guineensis Jacq.) In the main nursery session. The purpose of this research was to identify the effect of the application of oil palm shell biochar, rice husks, corn cobs, and coconut shells and obtain the appropriate dosage of biochar on the development of oil palm (Elaeis guineensis Jacq.) In the main nursery. The design used in the research was a non-factorial randomized block design ( $R B D)$ with 3 repetitions. There are also treatment aspects used are $B 0$ (compound fertilizer), B1 Biochar rice husk (50 gr/polybag), B2 Biochar oil palm shell (50 gr/polybag), B3 Biochar corn cobs (50 gr/polybag), B4 Biochar shell coconut (50 gr/polybag). Parameters observed were plant height $(\mathrm{cm})$, stem diameter (cm), number of leaves (strands), base wet weight (gr), base dry weight (gr), as well as analysis of $\mathrm{pH}, P$, and $K$ nutrients in the 
Agroteknika 4(1): 1-10 (2021)

soil. The results showed that the biochar treatment of oil palm shells, rice husks, corn cobs, and coconut shells did not significantly affect the observed parameters such as plant height (cm), stem diameter (cm), number of leaves (strands), base wet weight (gr) and base dry weight (gr). Conversely, in soil analysis, biochar treatment can increase $p H, P$ nutrients, and $K$ nutrients but only slightly.

Keywords: biochar, ultisol, palm oil, vegetative

\section{Pendahuluan}

Tipe tanah yang tersebar luas didaratan Indonesia adalah Ultisol. Tanah Ultisol merupakan tanah yang hadapi pelapukan tingkatan lanjut. Tanah Ultisol ialah salah satu tanah yang kurang produktif dan dimanfaatkan di dalam bidang pertanian maupun perkebunan serta dicirikan seperti akumulasin tanah liat di bagian horizon dasar permukaan mengurangi energi serap air dan tingkatkan aliran permukaan serta erosi tanah, permeabilitas, bahan organik dan tingkatan kebasaan rendah (Andalusia et al., 2016). Tanah Ultisol (acrisol maupun kelompok dalam ordo Ultisol yang kondisinya lebih kurang baik) sangat utama terdapat di Kalimantan bagian tengah dan timur laut.

Tujuan utama yang mempengaruhi pertumbuhan tanaman, yakni media tanam. Media tanam pada tanaman kelapa sawit pada dasarnya terdiri atas tanah top soil yang dicampur dengan pasir serta kompos organik sehingga menjadi media tanam yang produktif. Konsumsi kompos senantiasa menghasilkan dalam proses perbaikan tanah, mensuplai aspek hara untuk perkembangan tanaman, menyumbang penyebaran faktor hara yang cepat lewat biomassa mikroba. Namun, keuntungan tersebut akan menjadi jangka pendek, pemberian biochar dapat maningkatkan stabilitas pembenahan aspek hara pada tanah.

Biochar adalah arang hayati yang di hasilkan dari pembakaran bahan seperti tempurung kelapa dan lainnya sehingga menghasilkan unsur hara serta 50\% karbon (C) yang dapat dimanfaatkan untuk kesuburan tanah (Gani, 2010). Biochar merupakan suatu bahan kimia yang sekarang banyak digunakan dalam perusahaan industri dimana menggunakan proses absorpsi dan purifikasi (Soetomo, 2012). Potensi pada batok kelapa sangat luas pada areal tanaman perkebunan kelapa mencapai 3,79 juta hektar serta hasil produksi sama dengan kopra yaitu 2,94 juta ton/tahun dan dimana batok kelapa juga banyak digunakan sebagai biochar untuk pembenah tanah (Balai Penelitian Tanah, 2019).

Biochar yang ditambahkan dengan aplikasi pupuk organik ataupun anorganik, maka peran biochar akan dapat meningkatkan keseburan tanah bagi tanaman (Gani, 2009). Penambahan biochar pada tanah yang dimana dapat memperbaiki sifat fisik, sifat kimia dan sifat biologi tanah, dan biochar juga meningkatkan ketersediaan komponen kation dan unsur phosfor, unsur nitrogen dan kapasitas tukar kation tanah (KTK) dimana tanah tersebut semakin subur. 
Agroteknika 4(1): 1-10 (2021)

Peran utama pada biochar terhadap peningkatan pertumbuhan tanaman dapat dipengaruhi oleh aplikasi biochar yang diberikan (Gani, 2009). Menurut Ogawa and Yasuyuki (2010) mengatakan bahwa kualitas dari biochar sangat tergantung pada bahan yang digunakan seperti sekam padi, tempurung kelapa sawit, tempurung kelapa dan lainnya, cara pengolahan menggunakan metode karbonisasi seperti tipe alat pembakaran, suhu, dan bentuk fisik biochar yaitu padat, serbuk, karbon aktif. Menurut Oguntunde et al. (2004), kualitas biochar dipengaruhi oleh bahan yang digunakan serta kondisi pyrolisis (suhu, waktu, dan lainnya) yang juga berpengaruh terhadap stabilitas dan fungsi unsur hara pada biochar. Peningkatan hara phospor yang tinggi adalah dengan total $151 \%$, dimana menunjukkan bahwa phospor tidak mengalami penguapan pada suhu tinggi serta dalam proses pembakaran arang terjadi. Biochar dasarnya memiliki pH Alkalin dimana $\mathrm{pH}$ antara 8 hingga 9 serta sangat memberikan efek pengapuran (Oguntunde et al., 2008) dan luas pada permukaan biochar menjadikan Kapasitas Tukar Kation (KTK) sangat tinggi (Oguntunde et al., 2004; Liang et al.. 2006).

\section{Bahan dan Metode}

Penelitian dilakukan pada Lahan Praktikum Sekolah Tinggi Ilmu Pertanian Agrobisnis Perkebunan dan analisis tanah dilakukan di Laboratorium Asian Agri pada bulan Maret Agustus 2019. Bahan yang digunakan adalah tanah Ultisol, bibit kelapa sawit, biochar dari bahan sekam padi, tempurung kelapa sawit, tongkol jagung dan batok kelapa serta pupuk NPK 16-1616 sebagai pupuk dasar. Alat yang digunakan adalah drum pyrolisis (dekomposisi termokimia bahan melalui proses pemanasan tanpa atau sedikit udara yang akan mengalami pemecahan menjadi fase gas), gembor, cangkul, pisau cutter, meteran, amplop, timbangan analisis, saringan, $\mathrm{pH}$ meter dan alat lainnya.

Rancangan yang digunakan pada riset ini ialah Rancangan Acak Kelompok (RAK) non faktorial dengan perlakuan kontrol, sekam padi, tempurung kelapa sawit, tongkol jagung serta batok kelapa dengan dosis sebesar 50 gr/polybag dan menggunakan lima taraf perlakuan serta tiga pengulangan. Varietas bibit kelapa sawit yang digunakan ialah Dura x Pisifera Dumpy. Pengaplikasian pada perlakuan kontrol serta aplikasi biochar pada sekam padi, tempurung kelapa sawit, tongkol jagung dan batok kelapa yaitu (B): B0 = tidak ada pemberian, B1 = biochar sekam padi dengan dosis $50 \mathrm{gr} /$ polybag, B2 = biochar cangkang kelapa sawit dengan dosis 50gr/polybag, B3 = biochar tongkol jagung dosis 50gr/polybag, B4 = biochar batok kelapa dengan dosis 50gr/polybag. Hasil data di analisis secara statistika menggunakan uji Analysis of Varience (ANOVA) dengan uji lanjut Duncan's Multiple Range Test (DMRT) pada taraf 5\%. Data di analisis menggunakan aplikasi Statistical Analysis Software (SAS).

Paramater yang diuji adalah: pertumbuhan tinggi $(\mathrm{cm})$, diameter batang $(\mathrm{cm})$, jumlah daun (helai), berat basah pangkal (gr) dan berat kering pangkal (gr), $\mathrm{pH} \mathrm{H}_{2} \mathrm{O}$ tanah dengan metode 
elektrometry, analisis hara P (phosphor) menggunakan uji metode P-Bray II dan analisis hara $\mathrm{K}$ (kalium) menggunakan uji metode $\mathrm{NH}_{4} \mathrm{oAc} 1 \mathrm{~N}$ pH 7.

\section{Hasil dan Pembahasan}

\section{Tinggi Tanaman (cm)}

Pengujian tinggi tanaman dilakukan untuk mengetahui ukuran pertumbuhan tanaman kelapa sawit. Adapun hasil uji rataan tinggi tanaman terdapat pada Tabel 1.

Tabel 1. Rataan pertumbuhan tinggi tanaman.

\begin{tabular}{|c|c|c|c|c|c|c|c|}
\hline \multirow{2}{*}{ Perlakuan } & \multicolumn{6}{|c|}{ Pengamatan (MST) } & \multirow{2}{*}{ Rataan } \\
\hline & 6 & 8 & 10 & 12 & 14 & 16 & \\
\hline B0 & 38,90 & 40,22 & 41,68 & 43,01 & 44,57 & 45,53 & 42,32 \\
\hline $\mathrm{B} 1$ & 39,48 & 40,74 & 42,33 & 43,93 & 46,02 & 47,04 & 43,26 \\
\hline B2 & 39,92 & 41,27 & 41,82 & 43,67 & 45,06 & 46,24 & 43,00 \\
\hline B3 & 41,28 & 42,63 & 43,97 & 44,84 & 46,28 & 47,32 & 44,39 \\
\hline B4 & 40,71 & 41,97 & 43,22 & 44,73 & 46,18 & 48,32 & 44,19 \\
\hline Total & 200,29 & 206,83 & 213,02 & 220,19 & 228,10 & 234,47 & 217,15 \\
\hline Rataan & 40,06 & 41,37 & 42,60 & 44,04 & 45,62 & 46,89 & 43,43 \\
\hline
\end{tabular}

Berdasarkan Tabel 1, tinggi tanaman bibit kelapa sawit bervariasi, secara keseluruhan tinggi bibit dengan perlakuan B0, B1, B2, B3, B4 memiliki rataan sebesar 43,43 cm. Pertumbuhan bibit yang terendah dengan rataan $42,32 \mathrm{~cm}$ yaitu pada perlakuan B0. Sedangkan pertumbuhan tertinggi pada bibit yaitu pada perlakuan B3 dengan tinggi rataan 44,39 cm.

Pertumbuhan tinggi bibit minggu ke 16 setelah tanam pada perlakuan B3 menghasilkan bibit tertinggi sebesar 47,32 $\mathrm{cm}$ dan pertumbuhan tinggi bibit terendah pada minggu ke 6 yaitu pada perlakuan B0 sebesar 38,90 cm. Pengaplikasian biochar pada perlakuan B0, B1, B2, B3, B4 tidak berpengaruh nyata terhadap bibit kelapa sawit. Hal ini menyebabkan unsur hara dalam tanah sangat sedikit sehingga pertumbuhan tinggi bibit belum maksimal. Pertumbuhan vegetatif bibit sangat dipengaruhi oleh unsur hara NPK dan unsur hara lainnya dengan jumlah yang seimbang.

Menurut Lubis (2000) menyatakan bahwa unsur kalium mempunyai pengaruh penting dalam meningkatkan sintesis dan translokasi karbohidrat serta berfungsi untuk memperkuat tegakan pada batang bibit kelapa sawit dimana mempengaruhi diameter batang. Maka hal ini dikarenakan unsur hara yang terdapat pada tanah sangat kurang dan dampak pertumbuhan tinggi bibit belum maksimal. Pertumbuhan vegetatif bibit sangat dipengaruhi oleh unsur hara NPK dan unsur hara lainnya dengan jumlah yang seimbang.

Pertumbuhan tinggi tanaman tidak terlepas dari aktivitas sel meristem dalam tumbuhan, unsur hara kalium dan kalsium berperan penting dalam mempercepat pertumbuhan pada jaringan meristematik tanaman, sehingga dalam hal ini pemberian biochar mampu meningkatkan perkembangan tinggi bibit dan perbesaran diameter batang. Berbagai unsur hara yang ada pada 
biochar maka sangat berfungsi di aplikasikan pada tanaman untuk menambah pertumbuhan tanaman (Singh \& Fulekar, 2010).

\section{Diameter Batang (cm)}

Diameter batang bibit kelapa sawit diukur untuk mengetahui ukuran lilit batang. Adapun hasil uji rataan lilit batang bibit kelapa sawit terdapat pada Tabel 2.

Tabel 2. Rataan diameter batang

\begin{tabular}{|c|c|c|c|c|c|c|c|}
\hline \multirow{2}{*}{ Perlakuan } & \multicolumn{6}{|c|}{ Pengamatan (MST) } & \multirow{2}{*}{ Rataan } \\
\hline & 6 & 8 & 10 & 12 & 14 & 16 & \\
\hline B0 & 4,42 & 5,08 & 5,97 & 7,76 & 8,66 & 9,31 & 6,86 \\
\hline B1 & 4,47 & 5,24 & 6,32 & 7,44 & 9,63 & 10,29 & 7,23 \\
\hline B2 & 4,38 & 5,20 & 6,19 & 7,57 & 9,51 & 10,19 & 7,17 \\
\hline B3 & 4,43 & 5,46 & 6,53 & 7,74 & 10,03 & 10,69 & 7,48 \\
\hline B4 & 4,24 & 5,11 & 6,21 & 7,93 & 9,71 & 10,40 & 7,27 \\
\hline Total & 21,94 & 26,09 & 31,22 & 38,44 & 47,54 & 50,88 & 36,02 \\
\hline Rataan & 4,39 & 5,22 & 6,24 & 7,69 & 9,51 & 10,18 & 7,20 \\
\hline
\end{tabular}

Tabel 2 menunjukkan bahwa pengukuran diameter batang pada perlakuan seluruh yaitu dengan jumlah sebesar 7,20 cm. Pertumbuhan diameter batang yang terendah dengan rataan sebesar $6,86 \mathrm{~cm}$, yaitu pada perlakuan B0 dan pertumbuhan diameter batang yang tertinggi yaitu pada perlakuan B3 dengan diameter batang sebesar 7,48 cm.

Diameter batang pada minggu ke 16 setelah tanam terbesar yaitu pada perlakuan B3 dengan nilai 10,69 cm, sedangkan yang terkecil pada minggu ke 6 setelah tanam yaitu pada B4 sebesar 4,24 cm. Pada penelitian ini pemberian biochar ke tanah tidak berpengaruh nyata pada diameter batang tanaman. Hal tersebut dikarenakan perkembangan diameter batang sangat dipengaruhi oleh ketersediaan unsur hara didalam tanah tetapi ketersediaan hara pada tanah sangatlah sedikit. Kandungan unsur hara $\mathrm{K}$ dengan jumlah sedikit mengakibatkan diameter batang tanaman kurang berkembang dengan baik.

Menurut Munawar (2011) unsur fosfor (P) mempunyai fungsi dalam proses perkembangan tanaman yaitu proses terjadinya fotosisntesis serta metabolisme karbohidrat sebagai fungsi regulator pada tanaman.

\section{Jumlah Daun (helai)}

Pengamatan jumlah helai daun juga dianalisa untuk mengetahui pertumbuhan jumlah daun bibi kelapa sawit. Adapun hasil uji rataan jumlah daun terdapat pada Tabel 3. Dari Tabel 3 hasil rataan pertumbuhan jumlah daun yang tertinggi terjadi pada perlakuan B3 dengan rataan sebesar 9,11 helai. Sedangkan pertumbuhan jumlah daun yang terendah yaitu B0 dengan rataan sebesar 8,07 helai. Dari tabel tersebut bahwa jumlah unsur hara nitrogen yang tersedia pada tanah dapat di metabolisme baik oleh tanaman. Menurut Sutedjo (1999), bahwa nitrogen adalah unsur hara yang penting bagi perkembangan tanaman terutama untuk menyuburkan perkembangan daun. 
Agroteknika 4(1): 1-10 (2021)

Kebutuhan hara bagi tanaman kelapa sawit pada setiap fase pertumbuhannya berbeda. Menurut Lingga \& Marsono (2001) mengatakan jenis unsur yang paling penting dibutuhkan tanaman adalah unsur nitrogen. Unsur tersebut sangat dibutuhkan untuk menghasilkan protein lainnya dalam pembentukan sel baru serta berperan aktif dalam pembentukan klorofil daun.

Tabel 3. Rataan jumlah daun (helai)

\begin{tabular}{ccccc}
\hline \multirow{2}{*}{ Perlakuan } & \multicolumn{3}{c}{ Pengamatan (MST) } & \multirow{2}{*}{ Rataan } \\
\cline { 2 - 4 } & $\mathbf{8}$ & $\mathbf{1 2}$ & $\mathbf{1 6}$ & 8,07 \\
B0 & 7,11 & 8,00 & 9,11 & 8,59 \\
B1 & 7,56 & 8,67 & 9,56 & 8,67 \\
B2 & 7,67 & 8,78 & 9,56 & 9,11 \\
B3 & 8,11 & 9,33 & 9,89 & 8,59 \\
B4 & 7,22 & 8,44 & 10,11 & 43,04 \\
\hline Total & 37,67 & 43,22 & 48,22 & $\mathbf{8 , 6 1}$ \\
\hline Rataan & $\mathbf{7 , 5 3}$ & $\mathbf{8 , 6 4}$ & $\mathbf{9 , 6 4}$ & \\
\hline
\end{tabular}

Pertambahan jumlah daun yang tertinggi pada minggu ke 16 setelah tanam yaitu pada perlakuan B4 sebanyak 10,11 helai dan yang terendah pada minggu ke 6 setelah tanam yaitu pada perlakuan B0 sebanyak 7,11 helai. Pada perlakuan B0, B1, B2, B3, dan B4 tidak berpengaruh nyata pada penambahan bibit kelapa sawit. Hal ini dikarenakan adanya faktor genetik serta faktor lingkungan dalam perkembangan daun.

\section{Berat Basah Akar (gr)}

Berdasarkan pengolahan data yang dilakukan dengan uji rataan berat basah akar terdapat pada Tabel 4.

Tabel 4. Rataan berat basah akar (gr)

\begin{tabular}{cc}
\hline Perlakuan & Pengamatan \\
\hline B0 & 19,81 \\
B1 & 23,47 \\
B2 & 26,82 \\
B3 & 25,43 \\
B4 & 23,82 \\
\hline Total & 119,36 \\
\hline Rataan & $\mathbf{2 3 , 8 7}$ \\
\hline
\end{tabular}

\section{Berat Kering Akar (gr)}

Pengolahan data yang dilakukan dengan uji rataan berat kering akar terdapat pada Tabel 5 . Berdasarkan Tabel 5, bahwa berat kering akar pada perlakuan B2 menghasilkan berat yang lebih tinggi yaitu sebesar 7,77 gram jika dibandingkan dengan perlakuan lainnya. Sedangkan perlakuan B0 menghasilkan berat kering akar terendah yaitu 6,09 gram. Pada penelitian ini pengamatan berat kering akar pada semua perlakuan tidak berpengaruh nyata pada bibit kelapa sawit. Hal ini terjadi karena dosis pupuk pada saat diaplikasikan terlalu sedikit sehingga tanaman terjadi kekurangan hara. 


\section{Tabel 5. Rataan berat kering akar (gr)}

\begin{tabular}{cc}
\hline Perlakuan & Pengamatan \\
\hline B0 & 6,09 \\
B1 & 6,53 \\
B2 & 7,77 \\
B3 & 6,63 \\
B4 & 7,07 \\
\hline Total & 34,09 \\
\hline Rataan & $\mathbf{6 , 8 2}$ \\
\hline
\end{tabular}

\section{pH Tanah}

Hasil analisis tanah dilakukan pada laboratorium Asian Agri Kebun Bahilang dan diperoleh data $\mathrm{pH}$ tanah yang dapat dilihat pada Tabel 6.

\begin{tabular}{cc} 
Tabel 6. pH Tanah & \\
\hline Perlakuan & Rataan \\
\hline B0 & $4,92 \mathrm{c}$ \\
B1 & $5,47 \mathrm{a}$ \\
B2 & $4,76 \mathrm{c}$ \\
B3 & $5,20 \mathrm{~b}$ \\
B4 & $4,92 \mathrm{c}$ \\
\hline Total & 25,26 \\
\hline Rataan & $\mathbf{5 , 0 5}$ \\
\hline
\end{tabular}

Berdasarkan Tabel 6, perlakuan yang memiliki pH tertinggi yaitu pada perlakuan B1 dengan rataan sebesar 5,47 dan yang memiliki kadar $\mathrm{pH}$ terendah yaitu pada perlakuan $\mathrm{B} 2$ dengan rataan sebesar 4,76. Hal ini dikarenakan pemberian beberapa jenis biochar dapat menaikkan $\mathrm{pH}$ tanah jika dibandingkan tanpa biochar dan juga biochar lainnya.

Hasil analisis kadar hara tanah diatas menunjukkan bahwa pada perlakuan B1 dengan taraf biochar sekam padi sebanyak 50 gr/polybag memiliki nilai rataan tertinggi yaitu 5,47, sedangkan perlakuan B2 memiliki nilai terendah dengan rata-rata 4,76. Pada taraf perlakuan B0, B1, B2, B3, dan B4 berpengaruh nyata terhadap peningkatan $\mathrm{pH}$ dalam tanah. Menurut Saragih (2005) pengaplikasian biochar dapat memperbaiki keadaan tanah serta dapat menetralisasikan peningkatan pH, meningkatkan karbon organik, dan KTK.

\section{P-Tersedia}

Hasil analisis tanah yang dilakukan pada laboratorium Asian Agri Kebun Bahilang diperoleh data P-tersedia seperti yang terdapat pada Tabel 7. Dilihat dari Tabel 7, taraf perlakuan yang memiliki kadar hara $\mathrm{P}$ tertinggi yaitu pada perlakuan B3 dengan nilai rata-rata 76,67 dan yang memiliki kadar $\mathrm{P}$ terendah yaitu pada perlakuan $\mathrm{B} 1$ dengan nilai rata-rata 30,49 . Hal ini dikarenakan pemberian biochar tongkol jagung dapat menaikkan P, jika dibandingkan dengan biochar lainnya. 
Kemampuan tanaman kelapa sawit yang menyerap kadar hara P (phospor) yang diberikan pada tanah serta tidak terlepas dari tersedianya unsur hara yang memiliki dampak positif dalam membantu dalam proses penyerapan hara secara keseluruhan. Menurut Poerwanto (2003), unsur hara $\mathrm{P}$ (phospor) berperan dalam pembentukan sel, sehingga jika tanaman kekurangan hara phospor (P) maka perkembangan tanaman akan terhambat.

Tabel 7. P-tersedia

\begin{tabular}{cc}
\hline Perlakuan & Rataan \\
\hline B0 & 39,10 \\
B1 & 30,49 \\
B2 & 35,22 \\
B3 & 76,67 \\
B4 & 45,94 \\
\hline Total & 227,42 \\
\hline Rata-Rata & $\mathbf{4 5 , 4 8}$ \\
\hline
\end{tabular}

Hasil analisis kadar hara tanah diatas menunjukkan bahwa pada perlakuan B3 dengan taraf biochar tongkol jagung sebanyak 50 gr/polybag memiliki nilai rataan tertinggi yaitu 76,67, sedangkan perlakuan B1 yang memiliki nilai terendah yaitu rataan sebesar 30,49. Pengaplikasian yang diberikan pada tanah menunjukkan ketersediaan hara $\mathrm{P}$ menjadikan perkembangan tanaman kelapa sawit menjadi lebih baik. Unsur hara P (phospor) yang tersedia maka akan menghasilkan perkembangan akar yang baik.

\section{K-Tersedia}

Hasil analisis tanah yang dilakukan pada Laboratorium Asian Agri Kebun Bahilang diperoleh data ketersedian $\mathrm{K}$ yang dapat dilihat pada Tabel 8.

Tabel 8. K-tersedia

\begin{tabular}{cc}
\hline Perlakuan & Rataan \\
\hline B0 & 0,96 \\
B1 & 1,21 \\
B2 & 1,22 \\
B3 & 1,30 \\
B4 & 0,98 \\
\hline Total & 5,67 \\
\hline Rataan & $\mathbf{1 , 1 3}$ \\
\hline
\end{tabular}

Berdasarkan Tabel 8, taraf perlakuan yang memiliki kadar hara $\mathrm{K}$ tertinggi yaitu pada perlakuan B3 dengan rataan sebesar 1,30 dan yang memiliki $\mathrm{K}$ terendah yaitu pada perlakuan B0 dengan rataan sebesar 0,96 . Hal ini dikarenakan biochar yang digunakan memiliki K yang tidak terlalu tinggi sehingga biochar tidak terlalu efektif untuk meningkatkan K tukar di tanah ultisol.

Pengaplikasian biochar memberikan hasil yang kurang signifikan pada pertumbuhan serta perkembangan tanaman kelapa sawit, tetapi terjadi peningkatan pada tanaman jika dibandingkan dengan tidak diberikan biochar. Sebagai pembenah tanah, biochar mengandung unsur hara K 
yang dapat memperbaiki keterserapan hara $\mathrm{K}$ serta pertumbuhan tanaman. Menurut Widowati et al. (2012) hara kalium (K) yang terdapat pada biochar dapat berada di larutan tanah sehingga mudah terserap oleh tanaman dan juga peka terhadap pencucian. Pada penelitian ini pengamatan analisis tanah kadar hara K sangat rendah. Efektifitas biochar dalam meningkatkan kualitas suatu tanah sangat bergantung dan ditentukan oleh jenis bahan yang digunakan (Gani, 2009). Menurut Lehmann (2007) biochar yang diaplikasikan langsung pada tanah tidak terlalu meningkatkan fungsi pembenah tanah.

\section{Kesimpulan}

Berdasarkan hasil riset ini dapat dikatakan maka kadar hara $\mathrm{P}$ dan $\mathrm{K}$ yang tertinggi terdapat pada perlakuan B3 (biochar tongkol jagung) dengan nilai $\mathrm{P} 76,67 \%$ dan $\mathrm{K}$ dengan nilai 1,30\%. Pemberian biochar sekam padi, tempurung kelapa sawit, tongkol jagung, dan batok kelapa tidak memberikan pengaruh yang nyata terhadap perkembangan tanaman, diameter batang tanaman, jumlah helai daun, berat basah akar dan berat kering akar. Pemberian biochar sangat berpengaruh nyata pada peningkatan $\mathrm{pH}$ tanah sebesar $25,26 \%$.

\section{Daftar Pustaka}

Andalusia, B., Zainabun, Z., \& Arabia, T. (2016). Karakteristik tanah ordo ultisol di perkebunan kelapa sawit PT. Perkebunan Nusantara I (Persero) Cot Girek Kabupaten Aceh Utara. Jurnal Kawista Agroteknologi, 1(1), 45-49.

Balai Penelitian Tanah. (2019). Biochar Pembenah Tanah Yang Potensial. Agroinovasi. Diakses pada tanggal 26 Desember 2020. Retrieved from http://balittanah.litbang.go.id

Gani, A. (2009). Potensi Arang Hayati Biochar Sebagai Komponen Teknologi Perbaikan Produktivitas Lahan Pertanian. Iptek Tanaman Pangan, 4(1), 33-48.

Gani, A. (2010). Multiguna arang-hayati biochar. Sinar Tani Edisi, 2010, 13-19.

Liang, B., Lehmann, J., Solomon, D., Kinyangi, J., Grossman, J., O'neill, B., Skjemstad, J. O., Thies, J., Luizão, F. J., Petersen, J., \& Neves, E. G. (2006). Black carbon increases cation exchange capacity in soils. Soil Science Society of America Journal, 70(5), 1719-1730. https://doi.org/10.2136/sssaj2005.0383

Lingga, P. \& Marsono. (2001). Petunjuk Penggunaan Pupuk. Jakarta, Indonesia: Penebar Swadaya

Lubis, A. U. (2000). Kelapa Sawit. Teknik Budidaya Tanaman Perkebunan. Medan, Indonesia: Sinar.

Lehmann, J. (2007). A handful of carbon. Nature, 447(7141), 143-144.

Munawar, A. (2011). Kesuburan Tanah dan Nutrisi Tanaman. Bogor, Indonesia: IPB Press.

Poerwanto. (2003). Pengelolaan Tanah dan Pemupukan Kebun Buah-buahan: Bahan Ajar Budidaya Buah-buahan Modul VII. Bogor, Indonesia: Institut Pertanian Bogor.

Saragih, N. (2005). Beberapa Cara Pembuatan Arang Terhadap Mutu Arang Kelapa (thesis). Retrieved from https://repository.unri.ac.id/xmlui

Singh, D., \& Fulekar, M. H. (2010). Benzene bioremediation using cow dung microflora in two phase partitioning bioreactor. Journal of hazardous materials, 175(1-3), 336-343. https://doi.org/10.1016/j.jhazmat.2009.10.008

Soetomo, (2012). Keswadayaan Masyarakat Manifestasi Kapasitas Masyarakat Untuk Berkembang Secara Mandiri. Yogyakarta, Indonesia: Pustaka pelajar. 
Sutedjo, M. M. (1999). Pengantar Ilmu Tanah. Jakarta, Indonesia: Rhineka Cipta.

Ogawa, M., \& Okimori, Y. (2010). Pioneering works in biochar research, Japan. Soil Research, 48(7), 489-500. https://doi.org/10.1071/SR10006

Oguntunde, P. G., Abiodun, B. J., Ajayi, A. E., \& van de Giesen, N. (2008). Effects of charcoal production on soil physical properties in Ghana. Journal of Plant Nutrition and Soil Science, 171(4), 591-596. https://doi.org/10.1002/jpln.200625185

Oguntunde, P. G., Fosu, M., Ajayi, A. E., \& Van De Giesen, N. (2004). Effects of charcoal production on maize yield, chemical properties and texture of soil. Biology and Fertility of Soils, 39(4), 295-299. https://doi.org/10.1007/s00374-003-0707-1

Widowati, W., Asnah, A., \& Sutoyo, S. (2012). Pengaruh Penggunaan Biochar dan Pupuk Kalium Terhadap Pencucian dan Serapan Kalium pada Tanaman Jagung. Buana Sains, 12(1), 83-90. 